Article

\title{
Discursive Overlap and Conflictive Fragmentation of Risk and Security in the Geopolitics of Energy
}

\section{Luis Fernández Carril ${ }^{1}$, Roeb García Arrazola ${ }^{2}$ and Julio E. Rubio ${ }^{3, *}$}

1 Humanistic Studies, Tecnológico de Monterrey, Mexico City Campus, Mexico, D.F. 14380, Mexico; E-Mail: korn_sdz@yahoo.com

2 Sustainable Development, Tecnológico de Monterrey, Mexico City Campus, Mexico, D.F. 14380, Mexico; E-Mail: roebgarcia@itesm.mx

3 Metropolitan Mexico City Zone Directorate of Tecnológico de Monterrey, Mexico, D.F. 14380, Mexico

* Author to whom correspondence should be addressed; E-Mail: jerb@itesm.mx; Tel.: +52-55-5483-2399.

Received: 7 December 2012; in revised form: 23 February 2013 / Accepted: 25 February 2013 / Published: 7 March 2013

\begin{abstract}
As it touches all aspects of human activity and society in general, energy has become an object of discourse. Two main discourses have formed on the use of energy: risk discourse and security discourse. While environmental changes and oil depletion continue, a new application for the term security has appeared: energy security. This concept can be interpreted within the terms of risk discourse, which is oriented towards rational consensus and decision making, or as an exercise of power, sovereignty and hegemony. The boundaries between interpretations are often unclear. Thus, in an institutional framework that has fragmented principles, norms and rules, opposing discourses will overlap. Political agents and institutions deploy strategies based on these discourses. With this overlapping of discourses, the performative powers of different institutions clash, thus creating conflictive fragmentation in a governance architecture. The purpose of this investigation is to analyze the use of, replication of, and ambiguities surrounding the concept of energy security, so as to understand how and why these discourses overlap and the profound consequences that this overlap may have for present and future energy use, environmental negotiations, and political climate.
\end{abstract}


Keywords: energy security; discourse; risk society; conflictive fragmentation; climate negotiations

\section{Introduction}

The history and use of energy are intrinsically intertwined with the history of humanity. Fire was essential to the survival of the earliest human settlements, and the first human civilizations that harnessed the winds were able to sail and trade overseas. The industrial revolution led to a shift in power among countries, allowing countries such as England and France to become empires. In the 20th century, the arrival of nuclear energy led to further changes in international power structures. Energy is used both to sustain human life and to empower nations and countries. In this way, power and energy are fundamentally linked to human progress.

Thus, we can examine energy in light of many aspects of human experience, including progress, military power, economic dominance and the sustainability of human lifestyles. The different uses of the concept of energy have led to the development of discursive formations. French philosopher Michel Foucault, renowned for his studies on the relationship between power and knowledge, has described discursive formations in the following manner:

Whenever one can describe, between a number of statements, such a system of dispersion, whenever, between objects, types of statement, concepts, or thematic choices, one can define a regularity (an order, correlations, positions and functioning, transformations), we will say, for the sake of convenience, that we are dealing with a discursive formation ([1], p. 38).

Even statements that have been made in different ways and during different time periods can be grouped together when they refer to the same object of study. An object of study includes thoughts, representations, images and themes. Thus, discourse is practiced, reproduced, amplified, redistributed and diversified through time.

Energy has generated diverse discursive formations in which historical, economic and political aspects form thematic groups with different representations, uses and practices. Discursive formations evolve over time, absorbing new practices and sets of social and political conditions, or giving rise to new discourses.

Foucault [1] states that discursive practices create regularities when reproduced. However, he rejects any agency when analyzing how discourses are practiced by individuals or institutions-in other words, by subjects:

What we have called "discursive practice" can now be defined more precisely. It must not be confused with the expressive operation by which an individual formulates an idea, a desire, an image; nor with the rational activity that may operate in a system of inference; nor with the "competence" of a speaking subject when he constructs grammatical sentences; it is a body of anonymous, historical rules, always determined in the time and space that have defined a given period, and for a given social, economic, geographical, or linguistic area, the conditions of operation of the enunciative function ([1], p. 117). 
However, subjects are not only products of discourse. Subjects, agents or institutions can practice and reproduce discourses, and thus create and transform them:

In this definition of discourse and its role in a critical geopolitics, there are several aspects worth noting: first, the concept of discourse presented emphasizes the autonomy of the acting individual. Individuals shape discourses, draw on them intentionally, and deploy them strategically to pursue certain ends. While individuals may face constraints on their agency imposed through discourses, they have manipulative control over the structural conditions for their action ([2], p. 325).

When Müller [2] affirms that "individuals have manipulative control over the structural conditions for their actions," he alludes to the agency of individuals in geopolitics. Discourses become operational directives for individuals or agents. These discourses become operational when agents use them as a heuristic political practice, guided and directed by a specific discourse, to pursue certain ends.

As noted previously, discursive formations evolve over time and may give rise to new discourses, and independent discourses may become intertwined because of a specific object. As an object of discourse, energy is practiced and reproduced with different operational directives, creating discontinuities.

Foucault [1] acknowledges the existence of discourse discontinuities - such as ruptures, mutations, transformations and interruptions, whose status and nature vary considerably. These are the epistemological acts and thresholds that suspend the continuous accumulation of knowledge in the search for a new type of rationality and its various effects. These discourse discontinuities can become problematic:

The great problem presented by such historical analyses is not how continuities are established, how a single pattern is formed and preserved, how for so many different, successive minds there is a single horizon, what mode of action and what substructure is implied by the interplay of transmissions, resumptions, disappearances, and repetitions, how the origin may extend its sway well beyond itself to that conclusion that is never given - the problem is no longer one of tradition, of tracing a line, but one of division, of limits; it is no longer one of lasting foundations, but one of transformations that serve as new foundations, the rebuilding of foundations ([1], p. 5).

When there are discontinuities in discourse, whatever the reasons may be, new knowledge (savoirs) is created to repair the discontinuity. This new knowledge emerges from the struggle for power by different institutions seeking legitimacy. In the end, the institution with most legitimacy in the exercise of power is the one that establishes the new discourse continuities. The principal relevance of this is not that discourses are not coherent or that discontinuities may exist. As we shall see, there are interruptions, mutations, fragmentations and transformations within the concept of energy security as a byproduct of political institutions clashing while striving for political power.

Foucault's analysis aims to "uncover the principles and consequences of an autochthonous transformation that is taking place in the field of historical knowledge" ([1], p. 15). Although Foucault provides the foundation for discourse framework, our aim will be different. The purpose of this paper is not to analyze a discourse or to examine the historical evolution of discontinuities in energy discourse, but to uncover the fragmented and overlapped discourses employed by different agents, which have 
diverse types of rationalities, as part of a governance architecture. Thus, our focus is not only on energy as the object of discourse or its historical discontinuities, but on how fragmented and overlapping discourses create conflictive dynamics in the political arena when different institutions are striving for legitimacy for their respective energy discourses through the exercise of power.

\section{Fragmentation and Overlap}

According to Biermann, Pattberg, van Asselt and Zelli [3], fragmentation is a structural characteristic of any global governance architecture. They argue that

(...) high degrees of fragmentation are a frequent characteristic of global governance architectures, and conceptualizing governance architectures in different issue areas allows for the comparative analysis of different degrees and types of fragmentation. We advance the notion of global governance architecture in particular for this reason: because it allows for the analysis of (the many) policy domains in international relations that are not regulated, and often not even dominated, by a single international regime in the traditional understanding. Many policy domains are instead marked by a patchwork of international institutions that are different in their character (organizations, regimes, and implicit norms), their constituencies (public and private), their spatial scope (from bilateral to global), and their subject matter (from specific policy fields to universal concerns). These situations we understand as fragmented global governance architectures ([3], p. 16).

To assess levels of fragmentation, Biermann et al. [3] posit three levels of analysis: (1) the degree of institutional integration; (2) the extent to which core norms conflict; and (3) the existing actor constellations (i.e., which actors support which institutions).

In this manner, the authors [3] speak of three types of fragmentation: synergic fragmentation, cooperative fragmentation and conflictive fragmentation. Synergistic fragmentation refers to a global governance architecture in which almost all countries participate in the core institution in an issue area, and where this institution " provides for effective and detailed general principles that regulate the policies in distinct yet substantially integrated institutional arrangements" ([3], p. 20). This type of fragmentation can, for instance, be found in the issue area of ozone layer depletion. Cooperative fragmentation is when there are only loosely integrated institutions and decision-making procedures, when the relationship between the norms and principles of these different institutions is ambiguous, and/or when not all major countries participate in the core institution. Conflictive fragmentation occurs when the institutions in a given architecture are hardly connected or have very different decision-making procedures, when the principles, norms and rules are conflicting, or when the memberships of the institutions overlap in such a way that different actor coalitions accept or advance these conflicts.

Here, we would like to stress conflictive fragmentation and, in particular, the issue of principles, norms and rules of institutions that are hardly connected and thus lack coherence. If two or more discourses have the same object and are not compatible or mutually reinforcing, they become fragmented in an institutional or governmental framework. However, as we previously noted, "Individuals shape discourses, draw on them intentionally, and deploy them strategically to pursue certain ends" [2]. Thus, in an institutional framework with fragmented principles, norms and rules, opposing discourses 
will overlap. Accordingly, institutions with opposing discourses operate simultaneously and interact with each other, but are incompatible. This does not mean that they run parallel, but that there is, as Žižek [4] has identified, a "radical contingency of naming," which means that the performative power of discursive articulations strives for power in the political arena.

In this manner, international actors may deploy strategies based on antagonistic discourses that cover the same object of discourse without coherence. This can lead to mistrust, a lack of multilateral understanding and conflict when creating global governance architectures, as is the case with geopolitics.

The energy use and its evolution due to scientific and technological development have occasioned two intertwined principal discourses: risk discourse and security discourse. Risk discourse recommends responsible use of natural resources and energy technologies to avoid environmental disasters. Security discourse focuses on the unavoidable: scarcity, political instability, national sovereignty, protecting and safeguarding interests, and military power. Both discourses coexist and use the same object of discourse for different ends. They are practiced and operated by different political actors and may be used in opposing or antagonistic ways.

We shall analyze how risk and security discourses overlap in the concept energy security, to understand how this overlap creates unclear boundaries between operational interpretations of energy security and the possible geopolitical consequences of this ambiguous concept. First, we shall analyze the general characteristics and history of these discourses, to appreciate how they have been interpreted, reproduced and practiced.

\section{Risk Discourse}

Two elements drive risk discourse in modern societies: major disaster avoidance and environmental concerns. One of the first theorists to talk about a society driven by risk assessment was Ulrich Beck [5]. In his book Risk Society, first published in 1986, Beck argues that until recently modernity had undergone a period of tremendous technological and scientific progress without considering the finiteness of natural resources. The only risks that society considered were those related to institutions and government regulation. Nevertheless, an awareness of the consequences of "progress"overpopulation and unlimited military power-led to the concept of the Risk Society: a society that acknowledges that natural resources can be depleted and that human lifestyles are endangering ecosystems across the planet.

One possible consequence of Beck's idea of the risk society is the concept of responsible use of natural resources. For Beck, the main characteristic of the risk society is the rejection of an unambiguous instrumental rationality. He favors consensus among humans over individual rationality.

It is important to stress that, for Beck, risk is interpreted as a rational cognitive-preventive capability. When risk is understood by science, society or governments, countermeasures are implemented through international consensus, and the risk is avoided. Therefore, as soon as a risk is posed (e.g., scarcity of natural resources), forums, referendums and dialog among governments, businesses and citizens could lead to the beginning of plans of action for reducing or eliminating this risk. 


\section{Risk Discourse through Sustainability Discourse}

Sustainability discourse is derived from risk discourse. Its goals are the avoidance of environmental disasters, equilibrium between human consumption and natural resources, and conservation of natural resources through rational consensus and decision-making processes.

In the 20th century, different discoveries and scientific investigations have resulted in consciousness of the finiteness of natural resources. Nonrenewable resources such as oil and gas are the main sources of energy and thus have defined energy use. Every country in the world has based its economy and way of life on oil. Thus, every aspect of economic and human development depends on a nonrenewable energy source, making it the cornerstone of human life.

Sustainability has been a major subject since the publication of the Brundtland Report in 1987. It involves environmental concerns, the scarcity of natural resources and economic stability. In this report, the World Commission for Environment and Development defines sustainable development as:

[...] development that meets the needs of the present without compromising the ability of future generations to meet their own needs. It contains within it two key concepts:

- The concept of needs, in particular the essential needs of the world's poor, to which overriding priority should be given; and

- The idea of limitations imposed by the state of technology and social organization on the environment's ability to meet present and future needs ([6], p. 43).

In this manner, sustainability discourse incorporates the need for an increasing supply of natural resources and energy to deal with scarcity. Sustainability itself is part of risk discourse because it focuses on future events in which a rational decision-making process is the operational process for dealing with social and economic needs and environmental concerns.

\section{Security Discourse}

Security has been interpreted in terms of the relationships between states, and, consequently, in terms of the protection of national interests. One of the most renowned contemporary thinkers and scholars of security issues, Barry Buzan, defines security as follows:

Security is taken to be about the pursuit of freedom from threat and the ability of states and societies to maintain their independent identity and their functional integrity against forces of change which they see as hostile. The bottom line of security is survival, but it also reasonably includes a substantial range of concerns about the conditions of existence. Quite where this range of concerns ceases to merit the urgency of the "security" label (which identifies threats as significant enough to warrant emergency action and exceptional measures, including the use of force) and becomes part of everyday uncertainties of life is one of the difficulties of the concept ([7], pp. 432-433).

The words Buzan uses to describe security discourse include survival, threat and concerns for existence, among others. As we can see, these words could easily be seen as part of the same semantic group as risk. In both discourses, there is talk of avoidance, of danger recognition, and of decisions to 
be made in order to safeguard the interests of societies. What, then, are the differences between risk discourse and security discourse other than state-centeredness?

Buzan [8] examines two different interpretations of security that are important for understanding its complex role in the energy debate. First, the realist school argues that security is a result of power. In this manner, security is the exercise of power by a hegemon. Sovereignty is imposed to ensure the interests of the state. Second, the idealist school of thought postulates security as "a consequence of peace: a lasting peace would provide security for all” ([8], p. 2). However, through discourse, the concept of security becomes ambiguous. Securing interests could easily imply engaging in hostile activities while affirming the pursuit of peace.

From Beck's interpretation of the risk society and Buzan's interpretation of security, we can see that the risk perspective focuses on decision-making processes after a risk has been detected. By contrast, the security perspective emphasizes power and survival; however, security can be seen as peace, a result of the decision-making processes that are at the core of the risk perspective. Later works by Buzan, Waever and de Wilde [9] establish a broader concept of security, with five levels of analysis: international system, international subsystem, unit, subunit and the individual. The military sphere relates to power relations, the political arena to authority relations, the economic sphere to economic relations, the environmental sector to the relationship between humans and nature, and society to the relationships between social groups. In this work, Buzan et al. classify security for analytical purposes. However, in reality, these spheres overlap, so that classification or nominalism can be problematic given the complex task of separating "security" from other types of performative power, confirming what was seen previously with Žižek's radical contingency of naming.

Thus, the boundaries between risk discourse and security discourse are blurry. For example, interpretations of security frequently involve risk discourse interpreted both from an environmental disaster-avoidance perspective and a military perspective. Consequently, these discourses not only coexist, they overlap. Risk discourse is used as a security discourse, or vice versa, security is interpreted in terms of risk. This second possibility can become the source of conflict, as geopolitical conditions — and, as a result, energy management — evolve due to environmental change.

Risk and security discourses are interconnected with energy management. As we shall see, in the nuclear energy debate, these two discourses overlap. Depending on the matter at hand, nuclear energy is treated as a risk or as a national threat. The objective of one discourse is to avoid the other, to impose itself by force. Risk discourse attempts to impose itself through decision-making processes and rational consensus among peers, while security discourse does so through sovereignty and hegemony.

We will illustrate the evolution of this discursive overlap by analyzing the case of nuclear energy. With this example, we hope to shed light on how other applications of risk and security discourses overlap and clash in the energy debate in the 21 st century.

\section{Nuclear Energy Risk and Security Discourses}

According to Strydom [10], energy became the subject of a risk discourse in the 1950s and 1960s, in the form of a security assessment. Nuclear energy was interpreted as a military risk during WWII and the following years, when it was used as a weapon for the first time in the form of the atomic 
bombs detonated in Hiroshima and Nagasaki. Nuclear security became an important military and political issue during the Cold War.

Thus, strategic jostling for military and political power provoked the first assessments of energy risk. However, this apparent risk discourse on nuclear energy was really a security discourse. A clear example can be found in Dwight Eisenhower's speech Atoms for Peace at the UN in 1953:

I feel impelled to speak today in a language that in a sense is new, one which $\mathrm{I}$, who have spent so much of my life in the military profession, would have preferred never to use. That new language is the language of atomic warfare.

The atomic age has moved forward at such a pace that every citizen of the world should have some comprehension, at least in comparative terms, of the extent of this development, of the utmost significance to every one of us. Clearly, if the peoples of the world are to conduct an intelligent search for peace, they must be armed with the significant facts of today's existence ([11], Paragraphs 6-7).

Even in the 21st century, nuclear energy is still disputed within the context of security discourse. In 2009, US president Barack Obama was awarded the Nobel Peace Prize after signing a treaty with Russia that stipulates that both countries reduce their nuclear arsenals to a third of their original sizes, an agreement reminiscent of the Cold War. It has been argued that discourses evolve across time. For decades, Russia was the main nuclear threat to the US. Now, the main threats are Iran and terrorist movements. In his Nobel Prize celebration lecture, Obama demonstrates an understanding of nuclear energy in terms of security discourse:

One urgent example is the effort to prevent the spread of nuclear weapons, and to seek a world without them. In the middle of the last century, nations agreed to be bound by a treaty whose bargain is clear: All will have access to peaceful nuclear power; those without nuclear weapons will forsake them; and those with nuclear weapons will work towards disarmament. I am committed to upholding this treaty. It is a centerpiece of my foreign policy. And I'm working with President Medvedev to reduce America and Russia's nuclear stockpiles.

But it is also incumbent upon all of us to insist that nations like Iran and North Korea do not game the system. Those who claim to respect international law cannot avert their eyes when those laws are flouted. Those who care for their own security cannot ignore the danger of an arms race in the Middle East or East Asia. Those who seek peace cannot stand idly by as nations arm themselves for nuclear war ([12], Paragraphs 33-34).

The Eisenhower and Obama speeches reflect risk interpreted as nuclear security. Felix Ciută [13] identifies three "logics" behind the term energy security: a logic of war, a logic of subsistence and a "total security" logic. However, these distinct logics are part of the exact same discourse: security. The use of nuclear energy derives from sovereignty, national security, political power and peacekeeping. Nuclear energy is equivalent to nuclear weapons.

Though nuclear energy discourse was developed in the context of military risk, a second type of nuclear energy discourse was formed after a nuclear reactor meltdown in Chernobyl in 1986. The risk of a major environmental disaster caused by nuclear energy use became the dominant issue at stake in 
risk discourses. Since the end of the Cold War in 1991, risk discourses have tended to focus on environmental concerns.

The risk of nuclear disaster to the environment is still present today. In 2011, an earthquake caused a tsunami to crash into Japan, damaging a nuclear reactor. The threat of environmental disaster became explicit. The risk discourse developed in 1986 is apparent in the World Future Council (WFC) statement following the earthquake:

The tragedy in Japan has raised global awareness of the extreme dangers that can result from nuclear power generation. Grave as these dangers are, however, they are not as great as those arising from the possession, threat and use of nuclear weapons - weapons that have the capacity to destroy civilization and end most life on the planet.

The conclusion we draw from the nuclear power plant accident in Japan is that the human community, acting for itself and as trustees for future generations, must exercise a far higher level of care globally in dealing with technologies capable of causing mass annihilation, and should phase out, abolish and replace such technologies with alternatives that do not threaten present and future generations. This applies to nuclear weapons as well as to nuclear power reactors ([14], Paragraphs 6-7).

Thus, when a concept such as nuclear security is brought up, we can see that there are two discursive interpretations. The first interpretation focuses on the use of nuclear energy as a weapon and its destructive power. The second adopts an environmental risk perspective and holds that agreement is necessary to protect the environment from a major nuclear disaster.

However, although security and risk discourses overlap in the discussion on nuclear security, they can be easily identified and separated. The military applications of these two perspectives help us to distinguish between them. Still, a security discourse can be disguised as a risk discourse when dealing with broader concepts, such as energy, that have no obvious military applications. Environmental and geopolitical changes can create an overlap of concepts. This can have dangerous consequences, because the presence of differing notions of environmental security and energy security can trigger major conflicts during political negotiations on environmental issues involving international organizations such as the Intergovernmental Panel on Climate Change (IPCC) and the United Nations Framework Convention on Climate Change (UNFCCC). While negotiations are part of a decision-making process (through risk discourse), actions and geopolitics can follow security discourse in the realist interpretation of power, as Buzan explains.

The models that suggest the existence of peak oil and the inevitable depletion of oil have become a subject of risk discourse and have led to clashes between risk interpretations and assessments. In the following section, we shall explain how oil depletion changes the conditions of the existence of risk and security discourses.

\section{Peak Oil}

In 1956, M. King Hubbert [15] came to the conclusion that oil extraction would peak in the 1970s and then decline. Therefore, there would be a lack of a finite source of energy that affects every aspect of human life, threatening human life. 
However, in the anthropogenic climate change debate, these and later projections by Hubbert and others have been contested on the basis of panic-mongering, exaggeration and/or political agendas behind energy shifts. Risk is perceived and evaluated according to interests and ideologies. In 2008, British Petroleum's chief economist, Dr. Christof Rühl, provided a clear example of a counterargument within the framework of risk discourse. He proposed discarding the risk of oil depletion:

Physical peak oil, which I have no reason to accept as a valid statement either on theoretical, scientific or ideological grounds, would be insensitive to prices. In fact the whole hypothesis of peak oil-which is that there is a certain amount of oil in the ground, consumed at a certain rate, and then it's finished-does not react to anything. Whereas we believe that whatever can be turned into oil strongly depends on technology and technology depends on prices as well. Therefore there will never be a moment when the world runs out of oil because there will always be a price at which the last drop of oil can clear the market. And you can turn anything into oil into if you are willing to pay the financial and environmental price ([16], Section 9).

The statement by Dr. Rühl shows that risk is not a tangible object: it is a perception. Niklas Luhmann [17] understands the concept of risk as a prediction of a future event - a possibility, not an observable object - that makes people differ in their assessments. Thus, a potential loss such as oil depletion could be interpreted as a risk, which one can disregard as Dr. Rühl does, or as a danger or a threat.

To understand peak oil as a risk, it is important to stress that the world's oil supply will run out eventually, whether in 60 years or in 150. Discovery of oil deposits around the world has decreased. Oil discovery peaked in the 1960 s and, since then, deposits have decreased dramatically, although oil use continues to increase [18].

In addition to Dr. Rühl's argument, in recent years, discoveries of oil deep beneath Brazil, among other places, have provoked new oil curve projections. These new projections feed perceptions that the risk of oil depletion is limited, and they are used ideologically to stall climate negotiations by minimizing the perception of this risk. However, the new discoveries are not enough to meet global needs, according to a new comment by Murray and King in Nature [19].

While many new deposits have been discovered offshore or elsewhere, they are inaccessible. Arguments for oil depletion address the impracticality of accessing them. In this way, for example, Exxon affirmed in 2011:

(...) that for every 100 barrels it has pumped out of the earth over the past decade, it has replaced only 95. It's a conundrum shared by most of the other large Western oil-producing companies, which are finding most accessible oil fields were tapped long ago, while promising new regions are proving technologically and politically challenging [20].

In this last example, it is important to note how discourse is shifting from risk to security. When Gold and González [20] talk of a "conundrum," they refer to risk assessment. The transition to security is evident in the statement that "new regions are proving technologically and politically challenging." In this context, "politically challenging" means that oil is being found in regions with potential for conflict. Thus, risk discourse becomes security discourse. The remaining oil resources are largely in the Middle East, where a number of countries are hostile to the US but welcome negotiations with 
China. New regions can mean the Arctic ice retreat and the fight for resources, for example. Both have conflict potential. We will address these examples in greater detail later on in this article.

Hence, in the light of scarcity of natural resources, oil dependence has become the subject of security discourse as well. Oil consumption, like consumption of other nonrenewable energy sources, depends on the availability of oil and on demand for energy. A lack of oil is more than a risk. It is a threat, a matter of security.

As oil depletion continues and environmental conditions (such as the Arctic ice retreat) and geopolitics change, the race for resources will be carried out using power. However, when approached from a sustainability perspective, energy generates a risk discourse. Thus, negotiations stall, while geopolitics continues to evolve. Energy security involves both discourses and political actions.

Energy security is an ambiguous term with an unclear purpose. As we shall see in the next section, in the debates on alternative energy and peak oil, discursive formations are not as easily identifiable as in the nuclear security debate. Risk and security are not well defined, and this ambiguity leads to an increasingly problematic situation where environmental changes and global warming are concerned. Geopolitics and sustainability clash in more ways than through discourse.

\section{The New Energy Security Discourses}

As oil depletes, risk and security discourses are becoming entangled in the energy supply debate. This situation has given rise to the term energy security. However, as Buzan notes, the implications of the concept of security are ambiguous. The idealistic perspective finds security to be closely related to ensuring peace. Thus, the International Energy Agency (IEA) defines energy security as "the uninterrupted physical availability at a price which is affordable, while respecting environment concerns" ([21], Paragraph 1).

Defined this way, energy security projects sustainability discourse and provides a framework for environmental conservation. It also encompasses an economic discourse in which energy is seen as the main source of development for companies and countries. In this discursive approach, crisis is the outcome (and term) to avoid. Because energy is the foundation for economic growth, scarcity of energy resources is understood through a risk discourse interpretation.

Nonetheless, given its concern for the finiteness of resources, energy security is a matter of national security and geopolitics, reflecting Buzan's interpretation of security as a derivative of power. The emphasis of the risk perspective is placed on avoiding an energy crisis. However, this same energy crisis can be seen as a threat, a danger and a national security issue.

As noted earlier, security was traditionally understood in terms of military power. However, given the depletion of natural resources and an ever increasing demand for food, water, energy and resources in general, security is now defined in broader terms. New concerns include food security, water security and energy security. Scarcity of resources has become a political threat. Thus, energy security is now a component of national security.

In recent years, the environment has become increasingly a topic of security policy. While in the 1980s, the harmful effects of armament and war on health and the environment were at the center of the scientific and public debate. With the end of the Cold War, it became more and more apparent that environmental degradation and resources scarcities themselves can be the 
objects or (additional) triggers of conflicts, which can lead to the use of force. So it is not surprising that a discussion of concepts of expanded or environmental security was initiated, which are meant to extend beyond narrow military concepts of security. It was criticized, among other points, that transferring security mentality dominated by the military to the environmental sector would at the same time provide a gateway for the redefinition and relegitimization of military activities in environmental policy ([22], p. 195).

We can illustrate the realist interpretation behind the term energy security with an example. According to Froggatt and Levi, "as easily accessible sources of oil and gas become scarce, and remaining resources become ever more concentrated in unstable or unfriendly regions, energy security will require major changes, particularly for oil and the transport sector" ([23], p. 1). Thus, risk discourse is present in energy security discourse: the former as a derivative of sustainable development and the latter focusing on power relations. Both discourses are active: they replicate and overlap.

Energy security is understood and used differently by different political organizations. Through its multiple agencies, the UN promotes rational consensus based on decision-making processes. The UN espouses an idealistic interpretation of security. Following Beck and his Risk Society, international political will and technology can provide solutions for avoiding foreseeable future events where a risk is present; in this case, oil depletion and the need for a substitute source of energy. Thus, risk discourse dominates in the type of political agency described above, immersed in an idealistic perspective of security and Beck's view of the risk society. China's Premier Wen Jiabao applied this perspective in a speech at a UN meeting on sustainable energy:

"To save energy does not mean simply to cut energy use, nor does it compromise people's quality of life," Premier Wen told delegates. "What is needed is to rely on science and technology to increase energy efficiency, build a circular national economy featuring low input, high output and low energy consumption and emissions, and drive sustainable economic and social development with minimum energy and resource consumption."

He called on governments to "vigorously develop renewable energy and clean energy" as alternatives to fossil fuels, promote a "revolution of science and technology in the energy sector," and finally, "effectively safeguard energy security” ([24], Paragraphs 9-10).

In contrast to Beck, Luhmann believes that perceived risks generate structural conflict, not consensus. Decision making becomes highly debatable, and high-technology issues become paradigmatic cases. According to Strydom [10], Luhmann accepts that the spectacular upsurge of ecological risk generated by technological development led to the pronounced contemporary awareness of the high degree to which society endangers itself, and thus to the characteristic risk consciousness of our time. However, in contrast to Beck, who, especially in his earlier writings, suggests that adopting suitable technologies and dealing with them adequately would provide a solution to structural conflict, Luhmann traces the problem to a deeper level: the centrality of decision making in contemporary society.

Given climate change negotiations, environmental discourse has also become entangled with the geopolitics of energy. This is because climate change is largely due to current global energy policies, among other environmental issues with geopolitical implications, as we will see later on. Hence, at the UN, international negotiations regarding climate change and energy security are based on risk discourse and the idealist interpretation of security. However, after 17 years of stalled climate negotiations, 
environmental changes have become increasingly evident, and oil continues to deplete. Thus, risk becomes a more tangible object. Because of this, discourse on energy security, interpreted as a derivate of power, has become active in efforts to secure the remaining sources of nonrenewable energies.

Two examples can help to clarify this point. First, most of the remaining oil resources are located in politically unstable regions, such as the Middle East. Following Froggatt and Levi's interpretation of energy security, the race to satisfy energy needs lead to political and military confrontations. The exercise of power in order to secure energy resources has become frequent, such as in the Gulf and Afghanistan wars. New objectives become the target for "energy security":

The officials declined to describe the unusual contact between the two governments, and whether there had been an Iranian reply. Senior Obama administration officials have said publicly that Iran would cross a "red line" if it made good on recent threats to close the strait, a strategically crucial waterway connecting the Persian Gulf to the Gulf of Oman, where 16 million barrels of oil — about a fifth of the world's daily oil trade—flow through every day ([25], Paragraph 2).

As we noted previously, Iran has become an ally of China. Oil exports to China have increased. However, with Europe and the US imposing sanctions on Iran, China faces an oil conflict. Thus, nuclear safety discourse clashes with energy security discourse. In this manner, quoting the Chinese news agency Xinhua, Hornby states:

"China believes the Iran nuclear issue should be resolved peacefully through dialogues and negotiations, and that sanctions and military means will not fundamentally address the problem," Xinhua said, citing Chinese Assistant Foreign Minister Wu Hailong at the Friday meeting.

Xinhua said the Iranian side "expressed its willingness to resume talks" with six countries involved in discussions and to "strengthen cooperation" with the International Atomic Energy Agency, the UN's energy watchdog.

The US measures could potentially impact China, the largest buyer of crude from Iran, although the law allows an exemption for institutions in countries that have "significantly" reduced their dealings with Iran ([24], Paragraphs 4-6).

Thus, China can press Iran to cooperate with the US and Europe to secure its oil investments. China is trying to influence Iran because China's energy security is endangered by the imposition of US nuclear security discourse on Iran, the country with the world's third largest oil reserves. It would seem that in certain contexts, all energy discourses collide and overlap.

Still, the conflictive situation of oil in the Middle East is well known. A new geopolitical condition that involves oil depletion, environmental concerns and energy security is emerging as Arctic ice retreats, exposing new oil deposits. The fight for resources is performed through energy security discourse. However, it seems that Froggatt and Levi's interpretation of energy security as a manifestation of power and hegemony is still relevant, leaving the Arctic as a possible future conflict zone.

\section{The Arctic War Zone}

The consequences of climate change have given rise to a second geopolitical conflict concerning resource scarcity due to energy security issues, when these issues are interpreted as related to national 
security and political power. The Arctic is changing. Ice is retreating and leaving a new zone that can be exploited for its oil reserves, thus provoking a new conflict supported by an energy security discourse:

The melting of the Arctic ice cap in combination with developments elsewhere concerning future energy security are creating scenarios that range from low level friction to potential conflict between the Arctic littoral states. Much attention has been devoted to maritime boundary disputes involving the Arctic states: Canada, Denmark, Norway, Russia, and the US. In addition to this, the emerging interest of non-Arctic states in shipping, polar research and non-living resource exploitation also adds uncertain elements to the Arctic geopolitical development. Many Arctic states' populations are skeptical about non-Arctic states' intentions in the Arctic, thus raising such questions as, "Is China going to take away our oil and gas from the Arctic to meet its energy needs?" "Why are Japan and South Korea interested in observatory status in the Arctic Council?" Associated with these concerns is the essential question, "Is the energy factor a curse to Arctic cooperation or an opportunity to a peaceful settlement of Arctic maritime disputes?” ([27], Paragraph 1).

Hong's questions reflect the problem of energy security discourse. Will international energy supplies be ensured through rational consensus, through risk discourse and the IEA energy security interpretation, or through the use of military power and Froggatt and Levi's security interpretation? With the publication of a group of cables concerning the race for oil in the Arctic, Wikileaks provided a clue as to how this question might be answered. A 2010 cable quotes Russia's Ambassador to NATO [28] Dmitriy Rogozin as saying that "The twenty-first century will see a fight for resources, and Russia should not be defeated in this fight...NATO has sensed where the wind comes from. It comes from the North" ([29], Paragraph 5).

If these cables are representative, energy security will very likely be understood as Froggatt and Levi suggest. In the power interpretation, the term energy security is attributed to the state and its sovereignty. The preceding example speaks of a "fight" and of "defeat." If energy security is to be understood in this manner, the Arctic will become a war zone. Other labels can also be used to justify military action. If Arctic politics are labeled as being in a "state of emergency," this radical contingency of naming will create opportunities for justifying war, as Dittmer et al. stress:

This simple insight dovetails with well-established geopolitical understandings of power and discourse: the designation of spaces as exceptional, or not, enables particular kinds of interventions. Therefore, it is not climate change and Arctic exceptionalism that produce geopolitical interventions, it is the identification of climate change as a security issue, and the subsequent identification of the Arctic as a space of exception, that enable geopolitical intervention as the region is re-staged as a "state of emergency" ([30], p. 2).

However, as we have discussed, discourses overlap. The two interpretations of energy securityrisk discourse and security (as power) discourse - spread simultaneously not only between different states, but within these same states. This is not only a matter of state; as Buzan explains, this spread depends on the different governmental agencies and their specific operational interpretations and representations. In any given country, different governmental agencies may interpret energy security in different ways. States do not have uniform notions of energy security. In this manner, what the US 
Environmental Protection Agency (EPA) interprets as energy security might be completely different from the operational interpretation of the US Department of Defense (DoD). Individual agencies may not even have a fixed notion of what constitutes energy security or a defined governance structure. The Report of the Defense Science Board Task Force on DoD Energy Strategy demonstrates that this is that case within the DoD.

Finding \#3. The Department lacks the strategy, policies, metrics, information or governance structure necessary to properly manage its energy risks. Decisions that create energy demand are dispersed organizationally across the Department and throughout the Services, OSD, the Joint Staff and Defense Agencies; and functionally throughout JCIDS, preJCIDS planning, acquisition, procurement, policy, installations management, privatization, logistics, and so on. There is currently no unifying vision, strategy, metrics or governance structure with enterprise-wide energy in its portfolio. DoD efforts to manage energy are limited to complying with executive orders, legislation and regulations which are mostly limited to facilities, non-tactical fleet vehicles, purchase of renewable energy from utilities, and procurement of commercial products. These activities consume approximately a quarter of the Department's total energy. Efforts to manage energy to combat forces are generally limited to building logistics capacity to meet warfighter needs. These activities drive approximately three quarters of the Department's and have no single point of leadership, no policies, no metrics and no accountability ([31], p. 64).

In this manner, officials and agencies like the DoD will have different interpretations of energy security. Thus, the DoD and the EPA will interpret energy security differently, and their interpretations will also differ from those of climate officials sent to negotiate at the UNFCCC conferences, creating a conflictive fragmentation within the governance structure. This same situation is evident in China. There are agencies with different interpretations of energy security:

Actors throughout the Chinese bureaucracy are involved in the energy security debate. The most powerful stakeholders are the Chinese oil companies and the State Development Planning Commission (SDPC), followed by the now defunct State Economic and Trade Commission (SETC), the Ministry of Foreign Affairs (MFA) and the military. Less powerful stakeholders include economic and foreign policy research institutes, academics, and the media ([32], pp. 24-25).

These interpretations are operational. Discourses themselves are operational. Because of the overlap of discourses in the energy debate, conflictive fragmentation will prevail. Thus, conflict will arise as the environment changes and new geopolitical conditions are established.

\section{Conclusions}

As we have demonstrated, energy can become the object of discourse in different ways. In the case of nuclear energy, it is easy to identify risk discourse and security discourse, with security interpreted as power. Separating the elements that are specific to risk discourse from those that are unique to security discourse is straightforward. The use of nuclear energy to create weapons makes the difference between the two discourses discussed in this paper clear. Thus, even though nuclear security 
is invoked both as environmental disaster avoidance and as military power, context removes any ambiguity. These discourses overlap, but the boundaries between them can be identified.

However, in the case of general energy security, it is not as easy to identify the elements of these separate discourses without leaving a certain amount of ambiguity. Oil depletion and the energy debate can result in rational consensus and decision making, or in an exercise of power and hegemony meant to ensure or secure the remaining energy reserves. Both courses of action, though radically different, overlap in energy security discourse, making the ambiguity in their boundaries dangerous.

Discourses are operational. Different interpretations derive from different actions regarding the same object of discourse. Risk can be perceived and acted upon in different manners. As we have seen with peak oil, depletion can result in a sense of urgency to shift energy sources or, as in Dr. Rühl's case, to discard the risk. Thus, perceptions of risk clash, creating conflictive fragmentations. The peak oil debate parallels the general environmental debate regarding climate change. While one group of negotiations at the Conference of the Parts calls for action against climate change, another stalls the process to maintain the status quo, in complete disregard of the risks of inaction. The result is no effective plan of mitigation and the continuity of climate change effects.

Nonetheless, it is more dangerous when security interpretations clash and fragment the political process. As natural and geopolitical conditions change, oil continues to deplete and new exploration zones for oil exploitation appear, as in the Arctic. The term environmental security and its derivative, energy security, become increasingly important. Energy security can mean ensuring supply while making the transition to renewable energy sources or fighting for the remaining supplies. Ensuring and protecting can be peacekeeping measures or hegemonic practices. Disambiguation is unattainable because the same words are utilized in each discursive enunciation. Their semantics are the same. How they become operational is the only thing that separates one interpretation of security from another.

Moreover, both interpretations of energy security spread at the same time, not only within states, but within agencies. Thus, states do not have a consistent interpretation of energy security. The EPA may very well use a peacekeeping interpretation of security, while another governmental agency looks to the Arctic with hegemonic intentions.

While climate negotiations are driven by risk discourse, actions are increasingly becoming part of a security discourse as a means of hegemonic power. Hence, sovereignty is imposed. Environmental conflict will follow, not negotiations. With its unclear discursive boundaries, energy security becomes dangerous when new geopolitical conditions arise. Because of the use of nonrenewable energies and resultant carbon emissions, the climate and the environment will continue to change, and the stress on resources will continue to increase. In this way, concepts like energy security, food security and water security could easily cease to be part of sustainability discourse and may very likely become the next ideological excuses for armed conflicts during the 21 st century. The search for security can elicit cooperation or conflict. Consequently the term security, in whatever context it is used, should be carefully analyzed and defined in international negotiations, in order to arrive at a more standardized operational interpretation. More important, each context (such as the Arctic issue) requires its own consistent interpretation.

In this manner, we were able to observe that there are a large number of diverse international and national institutions involved in the geopolitics of energy-from the United Nations and other international agencies, to the Arctic Council and US government departments - that serve different 
purposes through the use of conflicting discourses. If discourses overlap, then performative powers overlap, creating conflictive fragmentation in governance architectures. The question would thus be: How can we reconcile discourses from the different institutions, agencies and strategies to cultivate coordination rather than fragmentation, and to avoid too many overlaps and conflicts?

\section{Acknowledgments}

We could like to thank Tecnológico de Monterrey and its Research Groups for their financial support and Lauren Jasie for language help and style review.

\section{Conflict of Interest}

The authors declare no conflict of interest.

\section{References and Notes}

1. Foucault, M. The Archaeology of Knowledge; Pantheon Books: New York, NY, USA, 1982.

2. Müller, M. Reconsidering the concept of discourse for the field of critical geopolitics: Towards discourse as language and practice. Polit. Geogr. 2008, 27, 322-338.

3. Biermann, F.; Pattberg, P.; van Asselt, H.; Zelli, F. The fragmentation of global governance architectures: A framework for analysis. Global Environ. Polit. 2009, 9, 14-40.

4. Žižek, S. The Sublime Object of Ideology; Verso: London, UK, 1989.

5. Beck, U. Risk Society; Sage: London, UK, 1986.

6. World Commission on Environment and Development. Our Common Future; Oxford University Press: Oxford, UK, 1987.

7. Buzan, B. New patterns of global security in the twenty-first century. Int. Aff. 1991, 67, 431-451.

8. Buzan, B. People, States and Fear: An Agenda for International Security Studies in the Post-Cold War Era; Pearson Education Limited: Harlow, UK, 1991.

9. Buzan, B.; Waever, O.; de Wilde, J. Security: A New Framework for Analysis; Lynne Rienner: Boulder, CO, USA, 1998.

10. Strydom, P. Risk, Environment and Society; Open University Press: Buckingham, UK, 2002.

11. Eisenhower, D. Atoms for Peace. Proceedings of the 470th Plenary Meeting of the UN General Assembly; New York, NY, USA, 1953. Available online: http://www.iaea.org/About/ history_speech.html/ (accessed on 22 January 2012).

12. Obama, B.H. Nobel Lecture-A Just and Lasting Peace; Oslo, Norway, 2009. Available online: http://www.nobelprize.org/nobel_prizes/peace/laureates/2009/obama-lecture_en.html/ (accessed on 22 January 2012).

13. Ciută, F. Conceptual notes on energy security: Total or banal security? Secur. Dialogue 2010, 41, $123-144$.

14. World Future Council. Joint Statement on the Japanese Nuclear Disaster, 2011. Available online: http://www.rightlivelihood.org/fileadmin/Files/PDF/others/Joint_Statement_on_the_Japanese_Nu clear_Disaster.pdf (accessed on 22 January 2012). 
15. Hubbert, M.K. Nuclear Energy and the Fossil Fuels. Proceedings of the Spring Meeting of the Southern District, Division of Production, American Petroleum Institute, San Antonio, TX, USA, 8 March 1956.

16. Rühl, C. BP: "We should see volatility increase.” EurActiv 2009, 481, 433-435.

17. Luhmann, N. Risk: A Sociological Theory; De Gruyter: Berlin, Germany, 1993.

18. Association for the Study of Peak Oil \& Gas. Statistics, 2010. Available online: http://www.peakoil.net/statistics/ (accessed on 11 February 2012).

19. Murray, J.; King, D. Climate policy: Oil's tipping has passed. Nature 2012, 481, 433-435.

20. Gold, R; Gonzalez, A. Exxon struggles to find new oil. Wall Street Journal, 16 February 2011. Available online: http://online.wsj.com/article/SB100014240527487044090045761463621173 13094.html/ (accessed on 16 January 2012).

21. International Energy Agency. Energy Security, 2012. Available online: http://www.iea.org/ subjectqueries/keyresult.asp?KEYWORD_ID=4103/ (accessed on 18 April 2012).

22. Scheffran, J. Environmental conflict and sustainable development: A conflict model and its application to climate and energy policy. In Environmental Change and Security: A European Perspective; Carius, A., Lietzmann, K.M., Eds.; Springer: New York, NY, USA, 1999; pp. 195-220.

23. Froggatt, A.; Levi, M.A. Climate and energy security policies and measures: Synergies and conflicts. Int. Aff. 2009, 85, 1129-1141.

24. Environment News Service. World Future Energy Summit Highlights Renewables, Sustainability, 17 January 2012. Available online: http://ens-newswire.com/2012/01/17/world-future-energysummit-highlights-renewables-sustainability/ (accessed on 20 January 2012).

25. Bumiller, E.; Smith, E.; Shanker, T.U.S. Sends top Iranian leader a warning on strait threat. New York Times, 12 January 2012. Available online: http:/www.nytimes.com/2012/01/13/world/ middleeast/us-warns-top-iran-leader-not-to-shut-strait-of-hormuz.html?_r=2\&pagewanted=all/ (accessed 29 January 2012).

26. Hornby, L. Reuters. China tells Iran to return to nuclear talks. Reuters, 20 January 2012. Available online: http://www.reuters.com/article/2012/01/21/us-nuclear-iran-china-idUSTRE80K05G20120121/ (accessed on 30 November 2012).

27. Hong, N. Arctic energy: Pathway to conflict or cooperation in the High North? J. Energy Secur. 2011, 15.

28. Russia it not a member of NATO, although the two entities often cooperate.

29. Greenpeace. Key Highlights from the Wikileaks Releases on 12 May 2011. Available online: http://www.greenpeace.org/canada/en/campaigns/Energy/climate-and-energy/Resources1/ Background-documents/Key-highlights-from-the-Wikileaks-releases-on-12-May-2011/ (accessed on 18 January 2012).

30. Dittmer, J.; Moisio, S.; Ingram, A.; Dodds, K. Have you heard the one about the disappearing ice? Recasting Arctic geopolitics. Polit. Geogr. 2011, 30, 202-214.

31. Department of Defense. Report of the Defense Science Board Task Force on DoD Energy Strategy, 2008. Available online: http://www.acq.osd.mil/dsb/reports/ADA477619.pdf (accessed on 29 January 2012). 
32. Downs, E.S. The Chinese energy security debate. China Q. 2004, 177, 21-41. Available online: http://www.globalcitizen.net/Data/Pages/1481/papers/20090619122948579.pdf (accessed on 1 January 2012).

(C) 2013 by the authors; licensee MDPI, Basel, Switzerland. This article is an open access article distributed under the terms and conditions of the Creative Commons Attribution license (http://creativecommons.org/licenses/by/3.0/). 